\title{
INNOVATIONS AND NEWS OF CONSUMER ELECTRONIC PRODUCTS
}

Chair: José Francisco Alvarenga - Assessor - ELETROS / Segmento de Áudio e Vídeo

\section{Co-chair: Alberto Deodato Seda Paduan - Consultant / SET}

- Presentation ELETROS and its associated companies -Evolution of the TV market since 2010

- Comparative of the semester sales volumes of SMART TVs and 4K TVs

- Accumulated sales of thin-screen TVs

- $\quad$ General information: analog signal shutdown, CRT TV estimate, extended band for FM radio.

- U.S. TELEVISION AND SMALL DEVICE SALES AND TRENDS Speaker: Mike Bergman - Senior Director, Technology and Standards | Consumer Technology Association

The Consumer Technology Association surveys its members for sales, sales trends and forecasts for the future. CTA also surveys U.S. consumers. This presentation will be a short overview of U.S. television and small device ownership, plus trends for features like screens size, UHD and HDR capability.

- DISPLAY TECHNOLOGY FOR TV SETS

Speaker: Igor Krauniski - Product Manager / TV - LG Electronics in Brazil

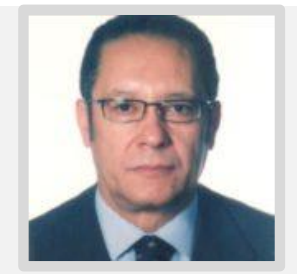

José Francisco Alvarenga - Assessor - ELETROS / Segmento de Áudio e Vídeo

Business administrator, he retired in 2010 from Philips do Brasil Ltda., where he was the Manager of both Trade Finance and Overseas Relations, responsible for representing the company at government level and in international negotiations with the countries of the Mercosur, the Andean Community and other ALADI countries. He is currently an advisor to ELETROS - the National Association of Electrical and Electronic Products Manufacturers, for the audio and video segment. He sits on the fiscal council of the FSBTVD and PSS - Seguridade Social.. 


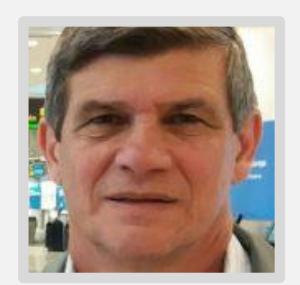

\section{Alberto Deodato Seda Paduan - Consultant / SET}

I studied Technician in Electronics in Santa Rita do Sapucaí, Operational Engineering, Business Administration and Post graduate in Economic Engineering in São Paulo. I have always worked as a radio and TV professional in the area of technical systems projects and, for the last 45 years, as an employee of TV Cultura de São Paulo. Currently I work in my company, providing consulting services, designing projects and monitoring facilities and assemblies in the same area of Radio and TV. I have been accompanying and writing information on the researches related to the television system in UHDTV since 2005. I participate in SET since 1992 where I wrote several articles for the magazine and where I acted as technical reviewer.

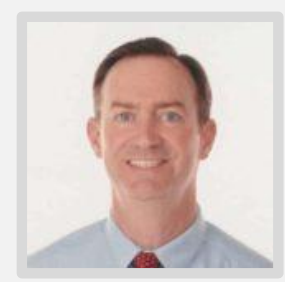

\section{Mike Bergman - Senior Director, Technology and Standards | Consumer Technology Association}

Mike has been in the electronics industry for more than 30 years, starting as a chip designer and progressing to embedded systems, wireless communications and wireless digital multimedia. Prior to CTA, he held senior positions at JVC-Kenwood, Sirius Satellite Radio, and several other wellknown tech companies in the computer and communications industries. He has two patents in semiconductor design, and has contributed to a number of standards including ATSC, DVB, NRSC and USB.

\section{Igor Krauniski - Product Manager / TV - LG Electronics in Brazil}

Graduated in Advertising and Propaganda from FAAP, with specialization in Business and Projects Management by FIA, he has 13 years of experience in the electronics segment and acts as product manager of the category TV at LG Electronics do Brasil, where he has dedicated special attention to the development of OLED technology in the Brazilian market in recent years. 